\title{
Tradisi Meurup-Urup dan Nilai-Nilai Karakter Masyarakat Banjar Munti Gunung Desa Tianyar Barat Kabupaten Karangasem
}

\author{
I Nengah Suastika ${ }^{1}$ \\ ${ }^{1}$ Universitas Pendidikan Ganesha, Indonesia
}

\section{A R T I C L E IN F O}

Article history:

Received 23 Juli 2020

Accepted 05 Mei 2021

Available online 30 Juni 2021

Kata Kunci:

Tradisi; Meurup-Urup; Nilai;

Keywords:

Tradition; Meurup-urup;

Values; Community

Character
Karakter Masyarakat

\begin{abstract}
A B S T R A K
Penelitian ini bertujuan untuk menganalisis dan memformulasi nilai-nilai karakter yang ada pada masyarakat Desa Munti Gunung yang dapat dijadikan modal sosial untuk membangun kemandirian masyarakat, memformulasi proses internalisasi sikap hormat dan bertangungjawab pada masyarakat Desa Munti Gunung, dan menganalisis implementasi sikap hormat dan bertangungjawab pada kehidupan masyarakat Desa Munti Gunung. Penelitian ini secara metodologis menggunakan pendekatan kualitatif. Subjek penelitian ini adalah tokoh masyarakat, anggota karang taruna, dan masyarakat. Objek penelitiannya adalah nilainila karakter dan kegiatan meurup-urup. Instrumen penelitian dalam penelitian ini, menggunakan prinsip bahwa peneliti adalah instrumen utama penelitian (human instrumen). Teknik analisis data dalam penelitian ini akan dilakukan secara kualitatif. Hasil penelitian menunjukkan pengembangan karakter masyarakat Banjar Munti Gunung dibangun dari
\end{abstract} landasan filosofis tri hita karana, sehingga membangun sikap jujur, bertangungjab, toleran, empati, kreatif, dan kebersamaan. Sedangkan proses internalisasi nilai-nilai karakter pada masyarakat Banjar Munti Gunung dibangun dari proses-proses kehidupan keluarga, organisasi sosial (sekeha), sekolah dan masyarakat. Penerapan nilai-nilai karakter, khsususnya sikap hormat dan tangungjawab terimplementasi pada semua aspek kehidupan masyarakat.

\section{A B S T R A C T}

This study aims to analyze and formulate the character values that exist in the Munti Gunung Village community, which can be used as social capital to build community independence, formulate the internalization process of respect and responsibility for the people of Munti Gunung Village, and analyze the implementation of respect and responsibility. on the life of the people of Munti Gunung Village. This research methodologically uses a qualitative approach. The subjects of this study were community leaders, members of the youth organization, and the community. The object of research is character values and meurup-urup activities. The research instrument uses the principle that the researcher is the leading research instrument (human instrument). The data analysis technique in this research will be done qualitatively. The results showed that the development of the character of the Banjar Munti Gunung community was built from the philosophical foundation of the tri hita karana, thus building an honest, responsible, tolerant, empathetic, creative, and togetherness attitude. Meanwhile, the process of internalizing character values in the Banjar Munti Gunung community is built from family life, social organization (sekeha), schools and the community. The application of character values, especially an attitude of respect and responsibility, is implemented in all aspects of community life. 


\section{Pendahuluan}

Masyarakat Bali saat ini dihadapkan pada berbagai persoalan, berkaitan dengan bangun karakter dan jati diri di tengah-tengah pengembangan industri pariwisata yang kian menggeliat (Adiani, 2010). Di satu sisi perkembangan industri pariwisata mampu membawa peningkatan perekonomian masyarakat dan kemajuan pembangunan. Namun pada sisi lain, perkembangan industri pariwisata telah membawa perubahan pola pikir yang bersifat rasional-materialis, yaitu berkembangnya prostitusi dengan berbagai ragamnya, menjamurnya cafe-cafe, maraknya perjudian, alih fungsi lahan pertanian, maraknya peredaran minuman keras, penyalahgunaan narkoba, dan maraknya Gepeng (gelandangan dan pengemis) (Suastika N., dkk. 2019). Kondisi ini menunjukkan telah terjadinya degradasi nilai-nilai moral religius pada masyarakat Bali. Sementara masyarakat Bali merupakan masyarakat religius yang kaya akan nilai-nilai budanya, yang dapat dijadikan sebagai pedoman dan landasan dalam menjalani serta menata kehidupan bermasyarakat. Nilai-nilai budaya dan agama yang bersifat adiluhung merupakan pedoman dalam berpikir, bersikap dan berprilaku bagi semua masyarakat Bali. Adapun nilai-nilai yang dapat dijadikan landasan berpikir, bersikap dan berprilaku oleh masyarakat Bali adalah filsafat tri hita karana, karakter menyama braya, karma phala, tatwam asi, saling asah, asih lan asuh, jengah, rwa bhineda, seguluk segilik selunglung sebayantaka dan lainnya (Atmadja, dkk. 2017).

Berbagai persoalan yang terjadi pada masyarakat Bali juga terjadi pada masyarakat Banjar Munti Gunung Desa Tianyar Barat. Bajar Munti Gunung Desa Tianyar Barat merupakan salah satu desa gersang yang terletak di daerah lereng Gunung Agung Kabupaten Karangasem. Untuk menopang kehidupan, masyarakat Bajar Munti Gunung Desa Tianyar Barat mengandalkan sektor pertanian, perkebunan, peternakan dan sektor jasa (kuli bangunan dan pekerja industri pariwisata) (Monografi Desa Tianyar Barat, 2015). Selain mengandalkan sektor pertanian, masyarakat Bajar Munti Gunung Desa Tianyar Barat juga sangat dikenal oleh masyarakat luar Karangasem karena adanya tradisi meminta-minta (mengemis). Pada awalnya tradisi ini terbangun dari proses merurup-urup (tukar menukar barang dengan masyarakat di desa lain) pasca terjadinya letusan Gunung Agung yang menyebabkan terjadinya krisis sambako pada masyarakat wilayah Kabupaten Karangasem dari tahun 1963. Semenjak itu masyarakat daerah Tianyar, Pedaan, Paleg dan Bajar Munti Gunung Desa Tianyar Barat terbiasa untuk menukarkan barang-barang hasil pertaniannya kapada masyarakat lain yang dikenal dengan istilah meurupurup. Adapun komuditas pertanian yang dijadikan sebagai objak pertukaran adalah jagung, garam, dan gula merah, yang ditukarkan dengan barang-barang yang berasal dari daerah lain, seperti beras, singkong, kelapa, buah-buahan dan uang. Masyarakat desa lain biasanya akan memahami proses meurup-urup ini dengan kegiatan yang bersifat semi-barter dan semi-amal, sehingga barang yang dipertukarkan tidak menggunakan ukuran yang setara. Tradisi meurupurup oleh masyarakat Bajar Munti Gunung Desa Tianyar Barat tidak dilakukan setiap saat, namun dilakukan secara musiman, yang biasanya dilakukan pada musim kering atau paceklik, dimana masyarakat Bajar Munti Gunung Desa Tianyar Barat tidak dapat menanam tanaman di areal pertaniannya. Untuk mengatasi keadaan itu, masyarakat Banjar Munti Gunung Desa Tianyar Barat menukarkan barang yang dimiliki (jagung, garam, gula merah) dengan barang-barang lain yang dibutuhkan, sehingga bisa terhindar dari kelaparan. Proses meurup-urup, merupakan salah satu bentuk nilai-nilai rasa hormat dan tangungjawab, terhadap diri sendiri dan keluarga, untuk tidak melakukan kegiatan mengemis (meminta-minta tanpa bekerja dan berusaha) dan tetap dapat terhindar dari kelaparan karena kekeringan. Meurup-urup dilakukan karena keadaan yang memaksa masyarakat Bajar Munti Gunung Desa Tianyar Barat saat itu, yang mengalami kekeringan, kesulitan mencari pekerjaan, kurangnya sarana transfortasi, pendidikan yang belum memadai dan kurangnya media informasi sebagaimana terjadi saat ini. Proses meurup-urup yang terjadi secara musiman ini akan berhenti ketika musim hujan telah turun dan masyarakat Bajar Munti Gunung Desa Tianyar Barat bisa menanam berbagai macam tanaman di tanah pertanian mereka. Bahkan ketika persediaan makanan dianggap mencukupi dibeberapa keluarga tradisi meurup-urup oleh keluarga tersebut akan dihentikan. Ini berarti tradisi meurup-urup dilkukan oleh masyarakat Desa Paleg, pedaan termasuk oleh masyarakat Bajar Munti Gunung Desa Tianyar 
Barat ketika mengalami kekeringan dan kekurangan persediaan makanan, sehingga mengancam terjadinya kelaparan. Sedangkan saat sudah tersedia bahan makanan maka masyarakat Bajar Munti Gunung Desa Tianyar Barat akan berhenti melakukan kegiatan meurup-urup.

Namun oleh generasi berikutnya, prosesi meurup-urup untuk mengatasi kekeringan dan kelaparan ini disalah maknai dan disalah gunakan untuk melakukan kegiatan meminta-minta atau mengemis. Proses mengemis ini tidak bersifat terorganisir atau dikoordinasi oleh Desa Dinas/Desa Adat atau kelompok tertentu, akan tetapi dilakukan secara pribadi-pribadi yang mengatas namakan masyarakat Bajar Munti Gunung Desa Tianyar Barat. Prose mengemis ini dilakukan di daerah perkotaan, seperti Denpasar, Gianyar dan Singaraja, khsusunya di daerahdaerah pariwisata (Pageh M., 2018). Akhirnya, masyarakat Bajar Munti Gunung Desa Tianyar Barat, salah satunya dikenal oleh masyarakat luar sebagai masyarakat yang mengemis. Mengemis ini lebih banyak dilakukan oleh kaum perempuan, yang kadang-kadang dengan memanfaatkan anak-anak untuk diajak mengemis dan dinilai lebih efektif untuk menggugah perasaan orang yang hendak bersedekah. Sedangkan, kaum laki-laki biasanya lebih banyak hanya menikmati hasil mengemis ini, hanya beberapa orang saja laki-laki yang melakukan kegiatan mengemis. Berdasarkan data monografi Desa Tianyar terungkap hanya sekitar 20\% laki-laki yang terlibat sebagai pengemis, dari keseluruhan pengemis yang ada di Bajar Munti Gunung Desa Tianyar Barat (Sukmana, 2020). Keterlibatan anak-anak dalam proses mengemis juga menyebabkan masih tingginya angka putus sekolah di Bajar Munti Gunung Desa Tianyar Barat. Diungkapkan oleh Kepala Desa Tianyar Barat, sekitar 20\% anak-anak usia Sekolah Dasar setiap tahunnya mengalami putus sekolah dan sekitar 34\% anak usia Sekolah Menengah Pertama yang mengalami angka putus sekolah. Data yang tersimpan di Dinas Sosial Kabupaten Karangasem mengungkap bahwa pada tahun 2015 jumlah gepeng yang berasal dari Dusun Muntigunung sebanyak 77 KK (225 jiwa) dan dari Dusun Pedahan (Kaja dan Kelod) sebanyak 21 KK (71 jiwa). Data tersebut merupakan perkiraan karena untuk menentukan jumlah yang pasti mengalami kesulitan terkait cara hidup gepeng yang tidak menetap dan mempunyai mobilitas yang tinggi (Kuntari \& Hikmawati, 2017).

Secara faktual masyarakat Banjar Munti Gunung Desa Tinyar Barat saat ini dihadapkan pada krisis identitas dan jatidiri, khsusunya rangsa hormat dan tangungjawab terhadap diri sendiri dan keluarga, sehingga menyebabkan menurunnya jiwa kewirausahaan dan kemandirian (Lickona, 2013). Hal ini tampak dari pola sikap dan prilaku yang ditunjukkan oleh masyarakat Banjar Munti Gunung Desa Tianyar Barat yang menjadikan proses mengemis musiman untuk mendapatkan uang yang digunakan untuk memperkaya diri dan berpoya-poya. Sementara secara substantif masyarakat Banjar Munti Gunung Desa Tianyar Barat semestinya sudah terhindar dari proses kelaparan dan kekeringan. Sebagian besar masyarakat sudah memiliki pekerjaan yang mampu mencukupi kebutuhan hidup keluarga (Monografi Desa Tianyar Barat, 2015). Terjadinya degrdasi moralitas ini tidak terlepas dari teralinasinya nilai-nilai budaya masyarakat proses pendidikan dilingkungan keluarga dan lingkungan masyarakat. Proses pendidikan di lingkungan keluarga tidak lagi menekankan pada internalisasi nilai moral religius diatas dominasi nilai materealisme pragmatisme. Nilai-nilai kerja keras, tangungjawab, kewirausahaan, rasa hormat pada diri sendiri dan keluarga dan kedisiplinan tidak lagi menjadi standar keberhasilan dalam membangun keluarga (Suastika N., 2014). Demikian juga dengan standar keberhasilan ekonomi, sosial dan budaya di masyarakat, tidak lagi menggunakan standar proses memperolehnya, akan tetapi apa yang mampu dihasilkan. Sehingga hasil akhirlah yang menjadi penentu dari setiap nilai yang dipeoleh. Kehormatan, pengakuan, keberhasilan dan eksistensi diri diukur dan dinilai berdasarkan pada berapa besar dan banyak materi yang dimiliki, bukan pada keberhasilan substantif untuk mengamalkan nilai-nilai kebaikan yang selama ini dijungjung tinggi untuk memperoleh pengakuan dan keberhasilan. Dominasi dan hegemoni praktik pendidikan keluaga yang cenderung mengabaikan nilai-nilai humanisme-religius, karena dikuasai oleh ideologi pasar kapitalisme yang cenderung materialistik, roh pendidikan keluarga dan masyarakat yang berlandaskan nilai-nilai moral yang suci kian waktu cenderung menampakkan gejala sekulerisasi (Atmaja N., 2008; Piliang seperti dikutip oleh Widja, 2007). Di sini pendidikan keluarga dan masyarakat, seperti sudah terpengaruh oleh negara sekuler, cenderung memisahkan antara 
kepentingan ideologi agama dan ideologi ilmu pengetahuan. Pada hal dalam realita masyarakat Bali pada cara berpikir dan nilai-nilai seperti ini bertentangan dengan nilai-nilai masyarakat yang religius. Dimana agama dan budaya masyarakat merupakan sumber sekaligus sebagai tujuan dari praktek pendidikan keluarga dan masyarakat (Sukadi, 2006). Bertalian dengan itu, tampaknya menganalisis phenomena mengemis mayarakat Banjar Munti Gunung Desa Tianyar Barat merupakan sesuatu yang bersifat urgen untuk membangun jatidiri dan kemandirian masyarakat, ditengah-tengah gempuran arus pragmatisme dan materialisme. Proses inilah yang akan menjadi dasar pengembangan dan internalisasi nilai-nilai karakter masyarakat Banjar Munti Gunung Desa Tianyar Barat.

\section{Metode}

Penelitian ini dilihat dari aspek pendekatan metodologinya menggunakan metode penelitian kualitatif dengan pendekatan studi etnografi (Miles and Huberman, 1992). Hal ini didasarkan atas analisis masalah penelitian, yang menuntut sejumlah informasi lapangan yang muncul dari bawah (Spradley J., 1980). Selain itu, studi etnografi mampu mengungkapkan data secara mendalam dan komperhensif mengenai aktivitas budaya masyarakat Banjar Munti Gunung Desa Tianyar Barat. Di dalam penelitian ini, yang menjadi informan penelitian adalah: (1) tokoh masyarakat bertalian dengan data kondisi sosial budaya masyarakat, nilai-nilai karakter masyarakat dan proses internalisasi nilai-nilai karakter, (2) karang taruna bertalian dengan nilainilai karakter, orientasi nilai karakter dan internliasasi nilai-nilai karakter, dan (3) anggota masyarakat bertalian dengan nilai-nilai karakter, internalisasi nilai-nilai karakter, dan tradisi merurup-urup pada masyarakat Banjar Munti Gunung Desa Tinayar Barat. Instrumen yang digunakan pada penelitian ini adalah pedoman observasi partisipasi, pedoman wawancara dan studi dokumen. Teknik penarikan dan pengembangan informan penelitian dilakukan secara bertujuan (purposive sampling tecnique), kemudian jumlah dan jenisnya dikembangkan secara "snowball sampling tecnique" bergulir sampai tercapainya kejenuhan data atau informasi/data telah terkumpul secara tuntas.

Instrumen penelitian dalam penelitian ini menggunakan prinsip bahwa peneliti adalah instrumen utama penelitian (human instrumen). Selama berlangsungnya pengumpulan data, peneliti dalam kapasitasnya sebagai instrumen penelitian, menggunakan beberapa alat bantu pengumpul data, seperti; (1) angket, (2) pedoman wawancara, (3) format observasi, (4) dan kamera foto sebagai alat perekam situasi. Berdasarkan prinsip human instrumen yang dianut dalam penelitian ini, maka jenis data yang dikumpulkan dalam penelitian ini meliputi kata-kata, tindakan, situasi dan peristiwa, serta dokumen yang dapat diobservasi (Miles and Huberman, 1992). Teknik pengolahan dan analisis data dalam penelitian ini dilakukan secara kualitatif, mengkategori dan mengklasifikasi data secara menyeluruh berdasarkan kaitan logisnya, kemudian ditafsirkan dalam keseluruhan konteks penelitian. Peneliti dalam kegiatan ini, berusaha memunculkan makna dari setiap data yang ada, sehingga tidak hanya bersifat deskriptif melainkan menyentuh dimensi transenden. Untuk mencapai hal itu, maka peneliti berusaha berpikir secara "divergen yang kreatif tetapi kritis" , sehingga subjektivitas pemaknaan terhadap keseluruhan data dapat dieliminir.

\section{Hasil dan Pembahasan}

Banjar Munti Gunung Merupakan salah satu banjar yang ada di Desa Tianyar Barat. Secara geografis wilayah Banjar Munti Gunung terletak di daerah lereng timur Gunung Batur yang termasuk wilayah Kabupaten Bangli. Namun, Banjar Munti Gunung merupakan wilayah Desa Tianyar Barat Kecamatan Kubu Kabupaten Karangasem. Masyarakat Banjar Munti Gunung Desa Tinyar Barat merupakan masyarakat Desa Bali Mula yang telah berkembang dan mendirikan pemukiman semenjak zaman kerajaan Beda Hulu. Sebagai salah satu masyarakat Bali Mula Banjar Munti Gunung Desa Tianyar Barat memiliki tradisi dan nilai-nilai yang sangat kuat berkaitan dengan kekerabatan, pelaksanaan ritual keagamaan, keyakinan dan pelaksanaan upacara untuk leluhur, proses pelaksanaan upacara siklus daur hidup, sistem sosial dan pelaksanaan adat 
istiadat. Berbagai persoalan yang terjadi pada masyarakat Bali juga terjadi pada masyarakat Banjar Munti Gunung Desa Tianyar Barat. Salah satu bukti sejarah yang menunjukan Banjar Munti Gunung sebagai desa tua tatanan bangunan puranya yang tidak memiliki Padmasana. Sejarah keberadaan Desa Munti berawal dari cerita kedatangan Trah Dalem Bujangga Sakti dari Nyalian, Bangli ke sisi timur Gunung Batur. Pada kedatangannya ini, Beliau mendirikan sebuah perkampungan yang diberi nama "Munti" yang berarti inti atau awal kehidupan (Pageh M., 2018). Kemudian dari sinilah masyarakat mengenal nama munti yang bermakan inti ada dasar dari sumber kehidupan. Karena munti terletak di lereng gunung, kemudian masyarakat menyebutnya dengan Munti Gunung. Kemudian, oleh masyarakat luas pemukiman masyarakat Banjar Munti ini dikenal sebagai masyarakat Banjar Munti Gunung.

Selain itu, ada juga ceritra lain yang tidak kalah menarik mengenai Munti Gunung, yakni mengenai sebuah sumber mata air abadi, yang oleh masyarakat menyebutnya mata air papad atau air penyambung nyawa. Mata air ini merupakan mata air satu-satunya yang terdapat di Munti Gunung, Tianyar, Kubu, Karangasem. Sumber mata air ini disebut sebagai air penyambung nyawa, karena di Munti Gunung hanya mata air ini yang menjadi satu-satunya sumber air sepanjang tahun. Semua masyarakat Munti Gunung menggantungkan hidupnya pada sumber mata air tersebut, terlebih di musim kemarau yang sangat sulit untuk mendapatkan air. Secara historis awal munculnya mata air papad, berawal dari kedatangan Dewi Danu yang berwujud laki-laki tua berpenampilan dekil dan kumuh membawa "tegenan" (pikulan) yang berisi air ke Munti Gunung. Kemudian laki-laki dekil tersebut menawarkan air yang dibawanya itu kepada masyarakat yang saat itu sedang melaksanakan "yadnya" (upacara keagaaman). Dikarenakan penampilan dari lakilaki tua tersebut kotor dan dekil lalu diusirlah oleh warga yang ada di Banjar Munti Gunung. Mendapat perlakuan seperti itu, laki-laki tua tersebut kemudian memberi kutukan lalu beranjak pergi. Adapun kutukan yang disampiakan pada masyarakat Munti Gunung adalah "kehidupan di Munti Gunung akan menjadi seperti dirinya". Setelah itu karena sudah mendapat penolakan, lakilaki tua tersebut melanjutkan perjalanannya sampai di satu tempat bernama Papad masih di wilayah Munti Gunung, laki-laki tua itu beristirahat, disanalah kemudian air yang dibawanya tumpah dan merembes ke bawah tebing hinga saat ini menjadi sumber air yang tidak pernah kering meski saat musim kemarau sekalipun. Saat ini rembesan mata air Papad ini dikeramatkan dan dijadikan sebagai tempat melukat oleh masyarakat sekitar. Mata air ini dipercaya berkhasiat seperti menyebuhkan penyakit kulit, bisa membuat umur panjang, penyegaran fikiran, dan peleburan hal-hal yang bersifat negatif (Pageh, 2018).

Secara ekonomi masyarakat Banjar Munti Gunung, merupakan masyarakat yang memiliki kemampuan ekonomi rendah. Untuk menopang kehidupan, masyarakat Bajar Munti Gunung Desa Tianyar Barat mengandalkan sektor pertanian, perkebunan, peternakan dan sektor jasa (kuli bangunan dan pekerja industri pariwisata) (Monografi Desa Tianyar Barat, 2015). Pada sektor pertanian masyarakat Banjar Munti Gunung mengandalkan tanaman kacang tanah, cabe rawit, jagung dan nangka. Tanaman ini biasanya bisa tumbuh dan berkembang dengan baik dimusin penghujan, sedangkan dimusim kering akan sangat sulit tumbuh dan berkembang. Pada sektor peternakan masyarakat Banjar Munti Gung mengandalkan peternakan sapi yang dikandangkan secara khsus dihalaman rumah. Ternak sapi selain dipelihara untuk dijual dagingnya juga dipelihara untuk dijadikan tenaga membajak ladang. Di samping memelihara sapi masyarakat Banjar Munti Gunung juga memelihara babi dan ayam sebagai kegiatan sambilan. Rata-rata mereka memeilihara babi 1 sampai 2 ekor dan ayam induk 3 sampai 7 ekor. Masyarakat Bajar Munti Gunung Desa Tianyar Barat juga sangat dikenal oleh masyarakat luar Karangasem karena adanya tradisi meminta-minta (mengemis). Pada awalnya tradisi ini terbangun dari proses merurup-urup (tukar menukar barang dengan masyarakat di desa lain) pasca terjadinya letusan Gunung Agung yang menyebabkan terjadinya krisis sambako pada masyarakat wilayah Kabupaten Karangasem dari tahun 1963. Semenjak itu masyarakat daerah Tianyar, Pedaan, Paleg dan Bajar Munti Gunung Desa Tianyar Barat terbiasa untuk menukarkan barang-barang hasil pertaniannya kapada masyarakat lain yang dikenal dengan istilah meurup-urup. Adapun komuditas pertanian yang dijadikan sebagai objak pertukaran adalah jagung, garam, dan gula 
merah, yang ditukarkan dengan barang-barang yang berasal dari daerah lain, seperti beras, singkong, kelapa, buah-buahan dan uang. Masyarakat desa lain biasanya akan memahami proses meurup-urup ini dengan kegiatan yang bersifat semi-barter dan semi-amal, sehingga barang yang dipertukarkan tidak menggunakan ukuran yang setara. Tradisi meurup-urup oleh masyarakat Bajar Munti Gunung Desa Tianyar Barat tidak dilakukan setiap saat, namun dilakukan secara musiman, yang biasanya dilakukan pada musim kering atau paceklik, dimana masyarakat Bajar Munti Gunung Desa Tianyar Barat tidak dapat menanam tanaman di areal pertaniannya. Untuk mengatasi keadaan itu, masyarakat Bajar Munti Gunung Desa Tianyar Barat menukarkan barang yang dimiliki (jagung, garam, gula merah) dengan barang-barang lain yang dibutuhkan, sehingga bisa terhindar dari kelaparan. Proses meurup-urup, merupakan salah satu bentuk nilai-nilai rasa hormat dan tangungjawab, terhadap diri sendiri dan keluarga, untuk tidak melakukan kegiatan mengemis (meminta-minta tanpa bekerja dan berusaha) dan tetap dapat terhindar dari kelaparan karena kekeringan. Meurup-urup dilakukan karena keadaan yang memaksa masyarakat Bajar Munti Gunung Desa Tianyar Barat saat itu, yang mengalami kekeringan, kesulitan mencari pekerjaan, kurangnya sarana transfortasi, pendidikan yang belum memadai dan kurangnya media informasi sebagaimana terjadi saat ini. Proses meurup-urup yang terjadi secara musiman ini akan berhenti ketika musim hujan telah turun dan masyarakat Bajar Munti Gunung Desa Tianyar Barat bisa menanam berbagai macam tanaman di tanah pertanian mereka (Pageh, 2018). Bahkan ketika persediaan makanan dianggap mencukupi dibeberapa keluarga tradisi meurup-urup oleh keluarga tersebut akan dihentikan. Ini berarti tradisi meurup-urup dilkukan oleh masyarakat Desa Paleg, pedaan termasuk oleh masyarakat Bajar Munti Gunung Desa Tianyar Barat ketika mengalami kekeringan dan kekurangan persediaan makanan, sehingga mengancam terjadinya kelaparan. Sedangkan saat sudah tersedia bahan makanan maka masyarakat Bajar Munti Gunung Desa Tianyar Barat akan berhenti melakukan kegiatan meurup-urup. Bahkan masyarakat, sangat anti terhadap kegiatan meminta-minta karena dinilai merendahkan harga diri dan masyarakat Banjar Munti Gunung.

Namun oleh generasi berikutnya, prosesi meurup-urup untuk mengatasi kekeringan dan kelaparan ini disalah maknai dan disalah gunakan untuk melakukan kegiatan meminta-minta atau mengemis. Proses mengemis ini tidak bersifat terorganisir atau dikoordinasi oleh Desa Dinas/Desa Adat atau kelompok tertentu, akan tetapi dilakukan secara pribadi-pribadi yang mengatas namakan masyarakat Bajar Munti Gunung Desa Tianyar Barat (Setiawan, 2020). Prose mengemis ini dilakukan di daerah perkotaan, seperti Denpasar, Gianyar dan Singaraja, khsusunya di daerah-daerah pariwisata. Akhirnya, masyarakat Bajar Munti Gunung Desa Tianyar Barat, salah satunya dikenal oleh masyarakat luar sebagai masyarakat yang mengemis. Mengemis ini lebih banyak dilakukan oleh kaum perempuan, yang kadang-kadang dengan memanfaatkan anak-anak untuk diajak mengemis dan dinilai lebih efektif untuk menggugah perasaan orang yang hendak bersedekah. Sedangkan, kaum laki-laki biasanya lebih banyak hanya menikmati hasil mengemis ini, hanya beberapa orang saja laki-laki yang melakukan kegiatan mengemis. Hanya sekitar $20 \%$ laki-laki yang terlibat sebagai pengemis, dari keseluruhan pengemis yang ada di Bajar Munti Gunung Desa Tianyar Barat. Keterlibatan anak-anak dalam proses mengemis juga menyebabkan masih tingginya angka putus sekolah di Bajar Munti Gunung Desa Tianyar Barat. Diungkapkan oleh Kepala Desa Tianyar Barat, sekitar 20\% anak-anak usia Sekolah Dasar setiap tahunnya mengalami putus sekolah dan sekitar 34\% anak usia Sekolah Menengah Pertama yang mengalami angka putus sekolah. Jadi secara filosofis masyarakat Banjar Munti Gunung melakukan aktivitas mengemis terbangun dari tradisi meurup-urup yang merupakan kegiatan barter untuk menanggulai kekeringan dan kelaparan yang terjadi di wilayahnya. Proses barter ini sifatnya pertukaran antara hasil pertanian masyarakat Munti Gunung dengan masyarakat lainnya, walapun dengan pertukaran yang tidak seimbang. Dengan demikian masyarakat Munti Gunung tidak melakukan kegiatan mengemis, namun melakukan barter untuk memenuhi kebutuhan hidup di musim kering. Namun begitu musim hujan tiba, masyarakat Munti Gunung akan melakukan aktivitas pertanian untuk memenuhi kebutuhan hidup, sehingga tidak lagi melakukan aktivitas barter. 
Masyarakat Banjar Munti Gunung merupakan bagian dari masyarakat Bali, yang memiliki nilai-nilai dan keyakinan yang sama dengan masyarakat Bali pada umumnya. Sebagaimana masyarakat Bali, masyarakat Munti Gunung membangun nilai-nilai dan keyakinan berdasarkan pada budaya, agama dan adat istiadat yang berkembang pada masyarakat Bali. Setangkup dengan itu, masyarakat Munti Gunung membangun kehidupannya berdasarkan ideologi tri hita karana sebagai tatanan harmoni hidup manusia dengan alam lingkungan, sesama, dan Tuhan Yang Maha Esa. Konsep ini juga merupakan konsep keseimbangan antara pemenuhan kepentingan materi dan atau kepentingan individu dengan kepentingan sosial dan kepentingan spiritual (Titib, 1995). Tri hita karana berasal dari kata tri yang berarti tiga; hita yang berarti sejahtera, bahagia, rahayu; dan karana yang berarti sumber penyebab. Jadi tri hita karana berarti tiga sumber penyebab adanya kesejahteraan, kebahagiaan, dan kerahayuan dalam hidup dan kehidupan semua makhluk ciptaan Tuhan. Ketiga penyebab kebahagiaan hidup itu adalah apabila dapat terwujud hubungan yang harmonis antara manusia dengan penciptanya (Tuhan Yang Maha Esa), manusia dengan sesamanya, dan manusia dengan lingkungan alamnya. Tri hita karana ini kemudian berkembang menjadi ajaran keserasian, keselarasan, keseimbangan, dan sealigus juga tentang ketergantungan satu sama lainnya dalam satu sistem kehidupan. Dikatakan demikian, karena, dalam pandangan masyarakat Hindu Bali, masyarakat selalu berusaha bersikap seimbang terhadap alam sekitarnya. Hal itu dilandasi oleh satu kesadaran bahwa alam semesta adalah kompleksitas unsur-unsur yang satu sama lainnya terkait dan membentuk suatu sistem kesemestaan. Kondisi ini dapat dilihat di Desa Tianyar Barat Banjar Munti Gunung dengan adanya Pura kayangan tiga, yaitu Puseh, Dalem dan Bale Agung. Pura puseh sebagai tempat bersetananya Dewa Wisnu sebagai Dewa pemelihara, Pura Bale Agung tempat bersetananya Dewa Brahma sebagai Dewa pencipta, Pura Dalem sebagai tempat bersetananya Dewa Siwa sebagai Dewa pelebur (Renawati, 2019).

Namun secara faktual masyarakat Banjar Munti Gunung Desa Tinyar Barat saat ini dihadapkan pada krisis identitas dan jatidiri, khsusunya rangsa hormat dan tangungjawab terhadap diri sendiri dan keluarga, sehingga menyebabkan menurunnya jiwa kewirausahaan dan kemandirian (Tateki Yoga Tursilarini dan Andayani Listyawati, 2015).. Hal ini tampak dari pola sikap dan prilaku yang ditunjukkan oleh masyarakat Banjar Munti Gunung Desa Tianyar Barat yang menjadikan proses mengemis musiman untuk mendapatkan uang yang digunakan untuk memperkaya diri dan berpoya-poya. Sementara secara substantif masyarakat Banjar Munti Gunung Desa Tianyar Barat semestinya sudah terhindar dari proses kelaparan dan kekeringan. Sebagian besar masyarakat sudah memiliki pekerjaan yang mampu mencukupi kebutuhan hidup keluarga (Monografi Desa Tianyar Barat, 2015). Terjadinya degrdasi moralitas ini tidak terlepas dari teralinasinya nilai-nilai budaya masyarakat proses pendidikan dilingkungan keluarga dan lingkungan masyarakat. Proses pendidikan di lingkungan keluarga tidak lagi menekankan pada internalisasi nilai moral religius diatas dominasi nilai materealisme pragmatisme. Nilai-nilai kerja keras, tangungjawab, kewirausahaan, rasa hormat pada diri sendiri dan keluarga dan kedisiplinan tidak lagi menjadi standar keberhasilan dalam membangun keluarga (Suastika N., 2014). Demikian juga dengan standar keberhasilan ekonomi, sosial dan budaya di masyarakat, tidak lagi menggunakan standar proses memperolehnya, akan tetapi apa yang mampu dihasilkan. Sehingga hasil akhirlah yang menjadi penentu dari setiap nilai yang dipeoleh. Kehormatan, pengakuan, keberhasilan dan eksistensi diri diukur dan dinilai berdasarkan pada berapa besar dan banyak materi yang dimiliki, bukan pada keberhasilan substantif untuk mengamalkan nilai-nilai kebaikan yang selama ini dijungjung tinggi untuk memperoleh pengakuan dan keberhasilan. Dominasi dan hegemoni praktik pendidikan keluaga yang cenderung mengabaikan nilai-nilai humanismereligius, karena dikuasai oleh ideologi pasar kapitalisme yang cenderung materialistik, roh pendidikan keluarga dan masyarakat yang berlandaskan nilai-nilai moral yang suci kian waktu cenderung menampakkan gejala sekulerisasi (Atmadja N., dkk, 2017). Di sini pendidikan keluarga dan masyarakat, seperti sudah terpengaruh oleh negara sekuler, cenderung memisahkan antara kepentingan ideologi agama dan ideologi ilmu pengetahuan. Pada hal dalam realita masyarakat Bali pada cara berpikir dan nilai-nilai seperti ini bertentangan dengan nilai-nilai masyarakat yang 
religius. Dimana agama dan budaya masyarakat merupakan sumber sekaligus sebagai tujuan dari praktek pendidikan keluarga dan masyarakat. Bertalian dengan itu, tampaknya menganalisis phenomena mengemis mayarakat Banjar Munti Gunung Desa Tianyar Barat merupakan sesuatu yang bersifat urgen untuk membangun jatidiri dan kemandirian masyarakat, ditengah-tengah gempuran arus pragmatisme dan materialisme (Suastika N., 2019). Proses inilah yang akan menjadi dasar pengembangan dan internalisasi nilai-nilai karakter masyarakat Banjar Munti Gunung Desa Tianyar Barat.

Secara relaistik masyarakat Bajar Munti Gunung Desa Tianya Barat saat ini sudah mengembangkan beberapa program yang mampu mengatasi terjadinya prilaku menggelandang dan mengemis (Amalia \& Samputra, 2020). Beberapa program tersebut adalah pelatihan pembuatan dupa, mejejaitan dan pengembangan desa wisata berbasis nilai-nilai tradisional masyarakat Banjar Munti Gunung. Untuk kegiatan membuat jejaitan sudah berjalan dan produk yang dihasilkan sudah terpasarkan bekerjasama dengan Yayasan Swagina Bali. Sedangkan untuk program membuat dupa, diakui masih perlu penyempurnaan khususnya dari segi kualitas. Dupa hasil produksi dari warga belum merata ketebalannya karena itu kualitasnya perlu di tingkatkan lagi. Guna meningkatkan kualitas dupa yang dihasilkan, tahun 2016 Pemkab Karangasem menyiapkan Rp. 300.000,- untuk pengadaan bantuan mesin produksi. Selain untuk meningkatkan kualitas, hadirnya mesin produksi tersebut diharapkan mampu meningkatkan hasil produksi, sehingga, dupa produksi masyarakat Banjar Munti Gunung bisa bersaing dengan dupa-dupa yang telah ada di pasaran. Selain itu Pemkab Karangasem melalui Dinas Sosial juga akan menjadikan Banjar Munti Gunung sebagai desa wisata. Program tersebut dinilai sangat potensial karena Banjar Munti Gunung punya banyak keunggulan seperti pemandangan perbukitan yang indah. Begitu pula dengan sejarah dari Munti Gunung sendiri (Suastika, 2019b).

Desa Tianyar Barat, Kecamatan Kubu, Kabupaten Karangasem mengembangkan Munti Gunung sebagai desa wisata Kawasan Strategis Pariwisata Nasional (KSPN) Tulamben. Langkah ini sebagai upaya meningkatkan pendapatan dan kesejahteraan masyarakat. Hal itu sebagai upaya memberdayakan sumber daya manusia (SDM) untuk membuka lapangan pekerjaan baru dan meningkatkan kreativitas masyarakat setempat (Suastika, 2019). Pihak Desa akan memaksimalkan pengelolaan daerah wisata tersebut sekaligus mengangkat pendapatan dan taraf hidup masyarakat setempat, sekaligus menghilangkan budaya gelandangan dan pengemis di daerah itu. Upaya itu didukung dengan pertumbuhan kreativitas ibu-ibu desa dalam mengolah daun lontar untuk untuk menghasilkan berbagai jenis cenderamata yang diperuntukkan bagi wisatawan. Selain itu, warga Munti Gunung juga mengembangkan kreativitas bahan kain seperti membatik usaha skala rumah tangga. Daerah Munti Gunung juga cocok untuk mengembangkan atraksi wisata seperti petualangan, outbond dan kegiatan spiritual. Desa Dinas bersama dengan Pemerintah Kabupaten terus melakukan terobosan dan inovasi pembangunan untuk mendukung berkembangnya desa wisata Munti Gunung. Upaya itu diharapkan mampu meningkatkan kualitas daya tarik wisatawan dalam dan luar negeri. Untuk itu, semua pihak, khususnya komponen pariwisata ikut serta memperomosikan desa wisata Munti Gunung. Desa Wisata Munti Gunung terletak di Desa Tianyar Barat Kecamatan Kubu Kabupaten Karangasem Bali dan tepatnya dusun ini terletak di lereng curam timur laut Gunung Batur. Antisipasi terhadap glandangan dan pengemis juga dilakukan dengan cara memberikan sanksi adat pada masyarakat Banjar Munti Gunung yang melakukan pekerjaan mengemis. Gelandangan dan pengemis dari Desa Munti Gunung, Kabupaten Karangasem, Bali, akan diberi sanksi adat jika tidak mau meninggalkan kebiasaannya dan terus melakukan aktivitas meminta-minta.

Kearifan lokal (local genius/local wisdom) merupakan pengetahuan lokal yang tercipta dari hasil adaptasi suatu komunitas yang berasal dari pengalaman hidup yang dikomunikasikan dari generasi ke generasi. Kearifan lokal dengan demikian merupakan pengetahuan lokal yang digunakan oleh masyarakat lokal untuk bertahan hidup dalam suatu lingkungannya yang menyatu dengan sistem kepercayaan, norma, budaya dan diekspresikan di dalam tradisi dan mitos yang dianut dalam jangka waktu yang lama (Atmadja N., dkk, 2017). Proses regenerasi kearifan lokal dilakukan melalui tradisi lisan (cerita rakyat) dan karya-karya sastra, seperti babad, 
suluk, tembang, hikayat, lontarak dan lain sebagainya. Kayakinan tradisional mengandung sejumlah besar data empiris yang berhubungan dengan fenomena, proses dan sejarah perubahan lingkungan sehingga membawa implikasi bahwa system pengetahuan tradisional dapat memberikan gambaran informasi yang berguna bagi perencanaan dan proses pembangunan (Eko, 2016). Nilai kearifan lokal yang berkembang dan diyakini sebagai perekat sosial yang kerap menjadi acuan dalam menata hubungan dan kerukunan antar sesama umat di Banjar Munti Gunung. Adapun nilai tersebut adalah kearifan Tri Hita Karana; suatu nilai kosmopolit tentang harmonisasi hubungan manusia dengan tuhan (sutata parhyangan), hubungan manusia dengan sesama umat manusia (sutata pawongan) dan harmonisasi hubungan manusia dengan alam lingkungannya (sutata palemahan). Nilai kearfian lokal ini telah mampu menjaga dan menata pola hubungan social masyarakat yang berjalan sangat dinamis (Geriya, I W., 1996). Nilai kearifan lokal tri kaya parisuda; sebagai wujud keseimbangan dalam membangun karakter dan jatidiri insani, dengan menyatukan unsur pikiran, perkataan dan perbuatan. Tertanamnya nilai kearfan ini telah melahirkan insane yang berkarakter, m emiliki konsistensi dan akuntabilitas dalam menjalankan kewajiban sosial. Nilai kearifan lokal Tatwam Asi; kamu adalah aku dan aku adalah kamu, nilai ini memberikan fibrasi bagi sikap dan prilaku mengakui eksistensi seraya menghormati orang lain sebagaimana menghormati diri sendiri. Nilai ini menjadi dasar yang bijaksana dalam membangun peradaban demokrasi modern yang saat ini sedang digalakkan. Nilai Salunglung sabayantaka, paras paros sarpanaya; sutu nilai sosial tentang perlunya kebersamaan dan kerjasama yang setara antara satu dengan yang lainnya sebagai satu kesatuan social yang saling menghargai dan menghormati (Sudarsana, 2017). Nilai Bhineka Tunggal Ika sebagai sikap sosial yang menyadari akan kebersamaan ditengah perbedaan, dan perbedaan dalam kebersamaan. Semangat ini sangat penting untuk diaktualisasikan dalam tantanan kehidupan social yang multicultural. Nilai kearifan lokal menyama braya; mengandung makna persamaan dan persaudaraan dan pengakuan social bahwa kita adalah bersaudara. Sebagai satu kesatuan sosial persaudaraan maka sikap dan prilaku dalam memandang orang lain sebagai saudara yang patut diajak bersama dalam suka dan duka (Gorda, IGN., 1996). Sederertan nilai-nilai kerafian lokal tersebut akan bermakna bagi kehidupan sosial apabila dapat menjadi rujukan dan bahan acuan dalam menjaga dan menciptakahn relasi sosial yang harmonis. Sistem pengetahuan lokal ini seharusnya dapat dipahami sebagai sistem pengetahuan yang dinamis dan berkembang terus secara kontekstual sejalan dengan tuntutan kebutuhan manusia yang semakin heterogen dan kompleks (Atmadja N., dkk, 2017).

\section{Simpulan dan saran}

Berdasarkan pada pembahasan di atas, dapat disimpulkan pengembangan karakter masyarakat Bajar Munti Gunung dibangun dari landasan filosofis tri hita karana, yaitu tiga hubungan harmonis yang menyebabkan terjadinya kesejahteraan. Internalisasi nilai-nilai karakter pada masyarakat Banjar Munti Gunung dibangun dari proses-proses kehidupan keluarga, organisasi sosial (sekeha), sekolah dan masyarakat. Namun dari semua proses-proses yang berpengaruh terhadap internalisasi nilai-nilai karakter tersebut adalah keluarga dan organisasi sosial. Hal ini disebabkan karena keluarga merupakan media pertama dengan durasi waktu yang paling panjang dari keseharian masyarakat Banjar Munti Gunung dan organisasi sosial (sekehe) memiliki hubungan yang bersifat horisontal dan vertikal, sehingga sangat ditakuti serta diikuti oleh semua anggota sekehe. Bertalian dengan itu, penguatan terhadap sanksi sosial sangat dibutuhkan untuk mengurangi pengemis di Banjar Munti Gunung Desa Tianyar Barat.

\section{Daftar Rujukan}

Adiani, H. (2010). Membentuk Manusia Berkarakter dan Beradab. (Makalah). Seminar Internasional UPI Bandung.

Amalia, L., \& Samputra, P. L. (2020). Strategi Ketahanan Ekonomi Keluarga Miskin Penerima Dana Bantuan Sosial di Kelurahan Tanah Tinggi Jakarta Pusat. Strategy Of Economic Resilience Of 
Poor Families Who Receive Sosial Assistance Funds In Tanah Tinggi Central Jakarta. Jurnal SOSIO KONSEPSIA, 9(2).

Atmadja, N. (2008). Metodologi Penelitian Kualitatif : (Makalah) disampikan Pada Pelatihan Dosen Muda Lemlit Undiksha Singaraja.

Atmadja, N. (2017). Agama Hindu, Pancasila dan Kearifan Lokal Pondasi Pendidikan Karakter. Singaraja: Pustaka Larasan.

Eko, P. (2016). Internalisasi Nilai-Nilai Karakter dalam Pembelajaran IPS Pada Siswa SM Negeri Model Terpadu Bojonegoro. Jurnal Metapora, 2(2), 91-104.

Gorda, IGN. (1996). Etika Hindu dan Perilaku Organisasi. Denpasar: Widya Kriya Gematama.

Geriya, I W. (1996). Pariwisata dan Dinamika Kebudayaan Lokal, Nasional, Global: Bunga Rampai Antropologi Pariwisata. Denpasar: Upada Sastra.

Kardji, I. W. (1993). Kiwa Tengen dalam Budaya Bali" dalam Jiwa Atmaja (ed.). Kiwa-Tengen dalam Budaya Bali. Denpasar: Kayu Mas.

Kuntari, S., \& Hikmawati, E. (2017). Melacak Akar Permasalahan Gelandangan Pengemis (Gepeng)

(Seeking The Root Of The Problems Of Beggar And Homeless). Jurnal Media Informasi Penelitian Kesejahteraan Sosial, 41(1), 11-26.

Miles dan Huberman. (1992). Analisis Data Kualitatif Buku Sumber Tentang Motode-Metode Baru. (Tjejep Rohendi Rohidi Penerjemah). Jakarta : UI Press.

Monografi Desa Tianyar Barat Tauhun 2015.

Lickona, T. (2013). Educating for Character. New York: Batam Book.

Pageh, M. (2018). Model Revitalisasi Ideologi Desa Pakraman Bagi Aga Berbasis Kearifan Lokal. Singaraja: Rajawali Press.

Renawati, W. (2019). Implementasi Upacara Manusa Yadnya dalam Naskah Dharma Kahuripan (Perspektif Teologi Hindu). MUDRA Jurnal Seni Budaya, 34(3).

Setiawan, H. H. (2020). Upaya Terpadu Pemerintah Kabupaten Pasaman Menanggulangi Kemiskinan (Integrated Efforts Of The Government Of Pasaman District To Poverty Alleviation). Jurnal SOSIO KONSEPSIA, 9(2).

Suastika, I. N. (2014). Pengembangan Model Pembelajaran IPS-SD Berbasis Multikultural (Studi Pengembangan Model Pembelajaran IPS-SD di Kota Singaraja). (Laporan Penelitian). Singaraja: Undiksha

Suastika, I. N. (2019). Folklore And Social Science Learning Model In Elementary School In Bali. Jurnal Kawistara, 9(2).

Suastika, I. N. (2019). Traditional Life Of Bayung Gede Community And Its Development As Cultural Attraction. International Journal of Applied Sciences in Tourism and Events, 3(1).

Sudarsana, K. (2017). Interpretation Meaning of Ngaben for Krama Dadia Arya Kubontubuh Tirtha Sari Ulakan Village Karangasem District (Hindu Religious Education Perspective). Internastional Journal of Hindu Science and Religious Studies, 1(1).

Sukadi. (2006). Pendidikan IPS sebagai Rekonstruksi Pengalaman Budaya Berbasis Ideologi Tri Hita Karana.(Disertasi). Bandung: UPI.

Sukmana, 0. (2020). Program Peningkatan Ketrampilanbagi Penyandang Disabilitas Netra (Studi Di Panti Rehabilitasi Bina Netra Malang, Jawa Timur). Jurnal SOSIO KONSEPSIA, 9(2).

Spradley, J. (1980). Participant Observation. New York: Holt, Rinehart and Winston.

Titib. (1995). Veda, Sabda Suci Pedoman Praktis Kehidupan. Surabaya: Paramita.

Tateki Yoga Tursilarini dan Andayani Listyawati. (2015). Peranan Nilai-Nilai Budaya dan Kearifan

Lokal dalam Pencegahan dan Penanganan Konflik Sosial. Media Informasi Penelitian

Kesejahteraan Sosial, Volume 39, Yogyakarta: Badiklit Kesos, B2P3KS Undang-Undang Nomor 11 tahun 2009 Tentang Kesejahteraan Sosial.

Undang-Undang Sistem Pendidikan Nasional No. 20 Tahun 2003

Widja. (2007). Membangun Kembali Jiwa Pendidikan dalam Sistem Persekolahan Kita (Satu Tinjauan Cultural Studies). Jurnal Pendidikan Dan Pengajaran Universitas Pendidikan Ganesh, $40(1)$. 